\title{
Alternative Sigma Factor HrpL of Pectobacterium carotovorum 35 is Important for the Development of Soft-rot Symptoms
}

\author{
Hyo-Song Nam ${ }^{\dagger}$, Ju Yeon Park ${ }^{1 \dagger}$, Beom Ryong Kang², Sung-Hee Lee ${ }^{3}$, \\ Jae Soon $\mathrm{Cha}^{4}$ and Young Cheol Kim ${ }^{1 *}$ \\ BioControl Center, Jeonnam Bioindustry Foundation, GokSeung 516-942, Korea \\ ${ }^{1}$ Institute of Environmentally-Friendly Agriculture, Chonnam National University, Gwangju 500-757, Korea \\ ${ }^{2}$ Jeonnam Agricultural Extension Service Center, Naju 520-715, Korea \\ ${ }^{3}$ Chungbuk Agricultural Research and Extension Services, Ochang 363-833, Korea \\ ${ }^{4}$ Department of Agricultural Medicine, Choongbuk National University, Chungju 361-763, Korea \\ (Received on May 31, 2011; Revised on July 15, 2011; Accepted on July 16, 2011)
}

\begin{abstract}
A bacterial artificial chromosome library of Pectobacterium carotovorum 35 was constructed to characterize the genome and to sequence its $h r p$ region. The $h r p$ cluster of $P$. carotovorum 35 consisted of 26 open reading frames in five operons. A promoter-based green fluorescent protein technology was used to identify the genes regulated by the alternative sigma factor, $\mathrm{HrpL}$, in $P$. carotovorum 35 . The majority of the selected clones contained the hrpJ operon promoter sequence, which harbors a $h r p$ box, but no putative hrp boxes were detected within the promoter sequences of two other $h r p L$-regulated genes encoding for pectate lyase and large repetitive protein. Although the promoters of five other $h r p$ operons also contained $h r p$ boxes, their expression was not HrpL-dependent in the promoter-based selection in $E$. coli. However, transcriptional analysis showed that expression from all operons harboring $h r p$ boxes, except for the $h r p N$ operon, was reduced significantly in the $h r p L$ mutant. The severity of soft-rot symptoms when the $h r p L$ mutant was applied to the surface of tobacco leaves, mimicking natural infection, was greatly attenuated. These results indicate that the hrpL gene of $P$. carotovorum 35 may be involved in the development of soft-rot symptoms.
\end{abstract}

Keywords : BAC end sequencing, Bacterial genomics, Hypersensitive and pathogenicity genes, Promoter-based expression technology, Soft-rot disease

\section{Introduction}

Pectobacterium carotovorum strains, which cause soft-rot disease, are plant pathogens with relatively broad host ranges (Perombelon and Salmond, 1995). The major virulence factors in soft-rot caused by $P$. carotovorum are extracellular enzymes, which macerate plant tissues. These enzymes include pectin-degrading enzymes, cellulases, and proteases (Andro et al., 1984; Collmer and Keen, 1986). Owing to the economic importance of soft-rot diseases, P. atroseptica SCRI1043 has been sequenced (Bell et al., 2004), and draft genome sequences for P. carotovorum and P. brasiliensis have been published (Glasner et al., 2008). Currently,

*Corresponding author

Phone) +82-62-530-2071, Fax) +82-62-530-2079

Email)yckimyc@chonnam.ac.kr

These authors are equally contributed to this work. we are working with the $P$. carotovorum 35 strain, which is responsible for massive losses of Chinese cabbage crops in Korea (Shin, 2004). In order to explore the genome of this strain, we generated a large-insert bacterial artificial chromosome (BAC) library. Such libraries have been extensively exploited in map-based gene cloning studies of eukaryotes (Zhang and Wing, 1997) and also in functional analyses of complex genomes (Antonarakis, 2001).

The hypersensitive response and pathogenicity ( $h r p$ ) gene cluster in plant pathogens plays a function in both pathogenicity and the hypersensitive response associated with plant resistance. The genes within the $h r p$ cluster encode for a type III-secretion machinery and bacterial effectors. The regulation of hrp gene expression is partially dependent on an alternate sigma factor, HrpL, which is encoded by the $h r p L$ gene within the hrp cluster (Frederick et al., 2001; Wei and Beer, 1995; Wei et al., 2000). HrpL activates transcription by binding to a common "hrp box", 5- 
GGAACCNA-N ${ }_{15-16}$-CCACNNA-3, located in the promoters of the responding genes (Fouts et al., 2002; Nissan et al., 2005; Xiao and Hutcheson, 1994). A promoter analysis of the HrpL-regulated genes in Pantoea agglomerans pv. gypsophilae demonstrated that the first five nucleotides of -35 (GGAAC) and the 3 nucleotide of the -10 (ACNNA) are crucial for HrpL recognition (Nissan et al., 2005). Genetic manipulation increasing the promoter strength of the HrpL-responding genes enhanced gall formation on $P$. agglomerans susceptible hosts (Nissan et al., 2005).

Recently, five $h r p L$ up-regulated genes, $h r p A, h r p K$, $d s p E, y i j C$ and yecF of Dickeya dadantii (Erwinia chrysanthemi), were identified by a green fluorescence (GFP)-based E. coli promoter-probe system (Shi and Cooksey, 2009). The functional roles of a few hrp genes of plant pathogenic Pectobacterium-related bacteria have also been identified. Mutants of the $h r p L$-regulated genes in $D$. dadantii evidenced reduced pathogenicity (Shi and Cooksey, 2009). Mutation of the HrpLregulated $h r c C$ gene in $P$. carotovorum did not impair pathogenicity, even though early growth on Arabidopsis was reduced (Rantakari et al., 2001). High expression levels of $h r p L$ and $h r p N$ genes in P. carotovorum were shown to negatively impact disease symptoms on Arabidopsis plants (Lehtimaki et al., 2003). These results indicate that $\mathrm{HrpL}$ may be a regulator of pathogenesis in $P$. carotovorum, even though no direct evidence supporting this notion has yet been published.

In this study, we identified a complete hrp cluster in P. carotovorum 35 from our BAC library, by comparison with the hrp cluster identified in P. carotovorum SCCI (Lehtimaki et al., 2003). In an effort to identify the genes regulated by $\mathrm{HrpL}$ in $P$. carotovora 35, we employed the GFP-based strategy used for $D$. dadantti (Shi and Cooksey, 2009), which identifies the promoters required for pathogenesis (Shi and Cooksey, 2009; Yang et al., 2004). We selected genes that were expressed only in the presence of HrpL. We evaluated expression from hrp operons harboring the Hrp box in the wild-type and $h r p L$-deficient mutants by quantitative reverse transcription-polymerase chain reaction analysis, and also assessed the role of $\mathrm{HrpL}$ in the virulence of $P$. carotovorum 35. Our findings indicated that the alternative sigma factor, HrpL, regulates the hrp box-harboring operons or genes in $P$. carotovorum 35, and may also be involved in the development of soft-rot symptoms.

\section{Materials and Methods}

Bacterial strains and growth conditions. $P$. carotovorum strain 35 , isolated from the roots of the Chinese cabbage (Shin, 2004), was stored in 15\% glycerol at $-80^{\circ} \mathrm{C}$. Luria-Bertani (LB) medium containing: Bacto-Tryptone $10 \mathrm{~g}$, Bacto-yeast extract $5 \mathrm{~g}, \mathrm{NaCl}$ $10 \mathrm{~g}, 11$ of distilled water and an $h r p$-inducing minimal medium containing : $\mathrm{KH}_{2} \mathrm{PO}_{4} 2 \mathrm{~g}, \mathrm{~K}_{2} \mathrm{HPO}_{4} 7.7 \mathrm{~g}, \mathrm{MgSO}_{4}$. $7 \mathrm{H}_{2} \mathrm{O} 0.1 \mathrm{~g}$, $\left(\mathrm{NH}_{4}\right)_{2} \mathrm{SO}_{4} 1 \mathrm{~g}$, glucose $4 \mathrm{~g}, 11$ of distilled water were used for growth (Huynh et al., 1989). For the liquid cultures, $P$. carotovorum 35 cells were grown with agitation at $100 \mathrm{rpm}$ at $27^{\circ} \mathrm{C}$. Escherichia coli cells containing the BAC clones were grown in LB or LB supplemented with $12.5 \mu \mathrm{g} / \mathrm{ml}$ of chloramphenicol. The media were amended with the appropriate antibiotics: tetracycline $(12.5 \mu \mathrm{g} / \mathrm{ml})$, ampicillin $(50 \mu \mathrm{g} /$ $\mathrm{ml})$, or kanamycin $(100 \mu \mathrm{g} / \mathrm{ml})$.

DNA manipulation. DNA manipulations for cloning and subcloning were conducted as described previously Ausubel et al. (1989) and Sambrook et al. (1989). Plasmids were isolated using a mini-plasmid purification system (Bioneer Inc., Daejeon, Korea). Transformation was conducted using an Electroporator (Cell-porator, Gibco BRL., USA). Nucleotide sequence analyses were conducted with an ABI1301 DNA sequencer (Applied Biosystems, Foster City, CA) at the Korea Basic Science Institute (KBSI), Gwangju Branch.

BAC library construction. High molecular weight chromosomal DNA of P. carotovorum 35 was prepared in low melting agarose gel, as previously described (Bell et al., 2002). The plugs containing high molecular weight $P$. carotovorum 35 chromosomal DNA were chopped into a slurry with a razor blade, washed, and partially digested with HindIII. The digested DNA samples were fractionated with a Bio-Rad CHEF Mapper and large fragments were cloned into the $\mathrm{BAC}$ cloning vector, pIndigoBAC-5 (Ma et al., 2000). Recombinant $\mathrm{BAC}$ clones were manually picked and stored in duplicate in 384-well plates at $-80^{\circ} \mathrm{C}$.

BAC end sequencing and cloning of $h r p$ cluster. The BAC clones were grown on LB containing chloramphenicol $(12.5 \mu \mathrm{g} / \mathrm{ml})$ and the DNA was isolated by the alkaline lysis miniprep method (Birnboim and Doly, 1979). The nucleotide sequences of the 504 BAC clones were determined with an ABI1301 DNA sequencer (Applied Biosystems, Foster City, CA) with the forward sequencing primer (5'-GGA TGT GCT GCA AGG CGA TTA AGT TGG-3') and the reverse sequencing primer (5'-CTC GTA TGT TGT GTG GAA TTG TGA GC-3') at Solgent Inc (Daejeon, Korea). The nucleotide sequences of the BAC clones were analyzed using the NCBI Blast program (http://www. ncbi.nlm.nih.gov).

On the basis of the BAC end sequencing results, the 
Table 1. Primers used in this study

\begin{tabular}{lll}
\hline \hline \multicolumn{2}{c}{ Primer } & \\
\hline$h r p N$ & $\mathrm{~F}$ & 5'-CCA TTC ATC CAG CCT GAA AT-3' \\
& $\mathrm{R}$ & GAC ATT ACC CCG GTA TGC TG \\
$h r p N \sim h r c C$ & $\mathrm{~F}$ & ACA GCT GTT CTG CGA TGT TG \\
& $\mathrm{R}$ & CGC TTT CAG TGG TTC GTG TA \\
$h r c \subset \sim h r p E$ & $\mathrm{~F}$ & GTC AGA GAC CGA GGC ATA GC \\
& $\mathrm{R}$ & CGA TGC GAT GAA GCT GAT TA \\
$h r p F \sim h r p B$ & $\mathrm{~F}$ & GTC AGA GAG CGA GGC ATA GC \\
& $\mathrm{R}$ & CGA TGC GAT GAA GCT GATTA \\
$h r p B \sim h r p A$ & $\mathrm{~F}$ & TTG TAC ACT TTT CGC CAC CA \\
& $\mathrm{R}$ & TGT CAA CAT GGC GCT GTA GT \\
$h r p S \sim h r p Y$ & $\mathrm{~F}$ & TGG CCG ATC TGC TAT TTA CC \\
& $\mathrm{R}$ & TGG TGC CAG AGG TTA CAT CA \\
$h r p Y \sim h r p L$ & $\mathrm{~F}$ & CTA CTC CTG AAG CCC AGA CG \\
& $\mathrm{R}$ & ACC CGT CGT TTT TCA CTG AC \\
$h r p L$ & $\mathrm{~F}$ & TTC CGT CAG TTT CTC GAT \\
& $\mathrm{R}$ & AAA TCG CAT CCT TGA TAC GG \\
$h r p J$ & $\mathrm{~F}$ & TTG CTG ACT CTC CGT TGT TG \\
& $\mathrm{R}$ & GCG TGG TGG AAA TGG AGA T \\
$h r p J \sim h r c Q$ & $\mathrm{~F}$ & AAC GGC GAT CCA ACT GAT AC \\
& $\mathrm{R}$ & CAC CAG ACG CAG GTT GTC TA \\
$h r c Q \sim h r c N$ & $\mathrm{~F}$ & GTT GGC AGC TAC AGG AGA GC \\
& $\mathrm{R}$ & GTA TCG GCA TCA GCA GGT TC \\
$h r c N$ & $\mathrm{~F}$ & CTG CGT CTG GTG AGA ATT GA \\
& $\mathrm{R}$ & GTA TCG GCA TCA GCA GGT TC \\
$h r p O \sim h r c S$ & $\mathrm{~F}$ & CAA GCA GGT TGA AAT GCT GA \\
& $\mathrm{R}$ & TGA TAG CCA ACT GCA TCA GC \\
$h r c R \sim h r c T$ & $\mathrm{~F}$ & GAT GCA GTT GCA GGATCA GA \\
& $\mathrm{R}$ & ATC GGC GTC TTC TAT GTT GG \\
$h r c T \sim h r c U$ & $\mathrm{~F}$ & CGG CCT GTT CTA CAG CTA CC \\
& $\mathrm{R}$ & GTC CCC GTA GCC AGA CAA TA \\
\hline & & \\
& & \\
& &
\end{tabular}

BAC clone E16 was ascertained to harbor the hrp gene cluster of $P$. carotovorum 35. DNA was isolated from the E16 clone by the alkaline lysis method and digested with various restriction enzymes, after which the fragments were subcloned into the designated plasmids. The hrp gene sequences were determined from the products of polymerase chain reactions (PCR), using primers based on the gene sequences in the hrp cluster of $P$. carotovorum SCC1 (GenBank accession number AY293288) (Table 1). The PCR products were purified and cloned into pGEM T-Easy vector (Promega, Madison, WI).

Replacement of $\boldsymbol{h r p L}$ promoter. The promoter of the $h r p L$ gene from $P$. carotovorum 35 was replaced with nptII and the construct was housed in E. coli DH5 $\alpha$ with pUC18. A reverse primer (5'-TCG GCA ACG CTC AAA TGC ATG-3') and forward primers harboring the nucleotide sequences of the partial $\mathrm{N}$ terminal sequence of $P$. carotovorum $35 \mathrm{hrpL}$ (underlined nucleotide sequences) were utilized in the construction of the nptII-hrpL sequence (5'-GCA CTA GAG CCC GGA ATT GCC AGC TGG GGC GCC CTC TGG
TAA GGT TGG GAA GCC CTG CAA ATG GAA ATG TCT ACC CTG AAA CAC ATC G-3'). PCR analysis with these primers yielded a $1.0-\mathrm{kb}$ product, which was purified by the methods described in the Nucleogen manual (NucleoGen Inc., Korea), cloned into pGEM T-Easy vector (Promega Inc., Madison, WI) and transferred into pUC18 prior sequencing in order to confirm the replacement of the promoter sequence.

A promoter probe-based GFP screening strategy. To construct the GFP promoter based library of $P$. carotovorum 35, the genomic DNA of $P$. carotovorum 35 was isolated by the CTAB-NaCl method (Ausubel et al., 1987). The genomic DNA of $P$. carotovorum 35 was partially digested with Sau3A1 and the approximately 2-kb genomic DNA fragments from agarose gels were isolated and purified with a Zymoclean gel DNA recovery kit (Zymo Research Inc., Orange, CA). The purified genomic DNA fragments of $P$. carotovorum 35 were cloned into the BamHI site of the promoter-probe vector, pPROBE-NT (Miller et al., 2000). A library of more than 20,000 clones was constructed, and each of the library plasmids was isolated by the CTAB method (Del Sal et al., 1989). The hrpL plasmid harboring the $n p t I I$-promoter-hrpL fusion was electroporated into $E$. coli DH5 $\alpha$, followed by individual purified plasmids with potential promoter-gfp fusions. Following electroporation, more than 20,000 ampicillin-resistant (selecting for the nptII-hrpL plasmid) and kanamycin-resistant colonies were isolated. The relative intensity of green fluorescence of each colony was measured with a Fluorometer $\left(\right.$ FLx $800^{\mathrm{TM}}$ Multi-Detection Microplate Reader, Bio-Tek Inc., USA). Plasmids from clones with high GFP expression levels were isolated and reintroduced into $E$. coli $\mathrm{DH} 5 \alpha$, which did not harbor the nptII-hrpL gene. Plasmids that evidenced low expression levels in the absence of $\mathrm{HrpL}$ were selected for further study. The plasmids of the selected clones were then purified, and each of the clones was subjected to DNA sequencing.

The promoter sequences of the $h r p N, h r p G, h r p A$, hrpJ, and hrcN operons from $P$. carotovorum 35, which harbored the putative hrp boxes, were amplified with the specific primer sequences (Table 1). The PCR products were subsequently cloned into pGEM T-Easy vector and DNA sequencing was performed to confirm the promoter sequences of each gene. Each of the PCR products was digested with EcoRI and cloned by ligation into the promoter-probe vector, pPROBE-NT, then electroporated into $E$. coli $\mathrm{DH} 5 \alpha$ harboring the plasmid containing the nptII-hrpL fusion. The relative green fluorescence of each colony was assessed with 
the Fluorometer (FLx800 ${ }^{\mathrm{TM}}$ Multi-Detection Microplate Reader, Bio-Tek Inc., USA).

Quantitative reverse transcription polymerase chain reaction analysis. $P$. carotovorum 35 cells were grown in $h r p$-inducing minimal and LB media. The cells were harvested at $\mathrm{OD}_{600 \mathrm{~nm}}=0.1$ for early-log phase cells, and at 2.0 for stationary-log phase cells. To confirm the expression of the hrp box containing genes, $P$. carotovorum 35 wild-type and hrpL mutant cells were grown to stationary phase in $h r p$-inducing minimal medium. Reverse transcription polymerase chain reaction (RT-PCR) analysis of RNA isolated from the $P$. carotovorum 35 cells was conducted using Trizol $^{\mathrm{TM}}$ (GIBCO BRL, Rockville, MD, USA) or an RNeasy Mini Kit with RNA protect Bacterial Reagent and RNase free DNase digestion (Qiagen, Valencia, $\mathrm{CA}$ ) in accordance with the guidelines provided in the user's manual in order to evaluate the expression of the hrp genes.

Quantitative RT-PCR was conducted using the QuantiTect SYBR Green reverse transcription-PCR kit (Qiagen Cat. No. 204243, Valencia, CA). The specific primers were as follows: forward ( $h r p L$ : 5'-ATC TGT CGA TTG CGA ACA GG-3', hrpJ: 5'-AAC GGC GAT CCA ACT GAT AC-3') and reverse ( $h r p L:$ 5'CTC CCG CAA ATT TAT CCT GA-3', hrpJ: 5'-ACA GAT TCA TGG CTG CTC CT-3'). Specific primers for the 16S rRNA gene, forward (5'-TGG CTC AGA ACG AAC CCT GGC GGC-3') and reverse (5'-CCC ACT GCC TCC CGT AAG GA-3'), were used as internal standards. A $25 \mu \mathrm{l}$ mixture was incubated for $30 \mathrm{~min}$ at $50^{\circ} \mathrm{C}$ for reverse transcription, followed by quantitative PCR. A Rotor-Gene 2000 Real Time Cycler machine (Corbett Research Inc., Sydney, Australia) was operated for 35 of following cycles: denaturation at $94^{\circ} \mathrm{C}$ for $15 \mathrm{~s}$, annealing at $55^{\circ} \mathrm{C}$ for $30 \mathrm{~s}$, and a $30 \mathrm{~s}$ extension step at $72^{\circ} \mathrm{C}$. Software manufactured by Corbett Research Inc., Australia, was used to determine the expression of the target genes. The comparative $C_{T}$ method ( $2^{-\Delta \Delta C T}$ method) was employed to determine the expression level of the analyzed genes (Livak and Schmittgen, 2001). The expression of the target genes was normalized using the $16 \mathrm{~S}$ rRNA gene fragment as a housekeeping gene. Fold units were calculated by dividing the normalized expression values of the target genes in the hrpL mutant by the normalized expression values of those in the wild-type strain. The results are expressed as the mean and standard deviation of three replicates.

Production of extracellular enzymes. Growth conditions, preparation of culture supernatants, and assay conditions for cellulase, pectate lyase, polygalacturonase, and protease were described previously (Chatterjee et al., 1985; Murata et al., 1991). After $16 \mathrm{~h}$ to $18 \mathrm{~h}$ at $28^{\circ} \mathrm{C}$, pectate lyase and polygalacturonase assay plates were developed with $4 \mathrm{~N} \mathrm{HCl}$, and the cellulase assay plates were developed with Congo red and $\mathrm{NaCl}$ solutions solutions (Barras et al., 1987; Chatterjee et al., 1985). Halos around the wells arising as the result of protease activity became visible in the protease assay plates within 24 to $36 \mathrm{~h}$ without any further treatments.

Construction of hrpL mutant. The hrpL gene was disrupted by the insertion of an EcoRI fragment containing a kanamycin resistance gene from plasmid pRL648 (Elhai and Wolk, 1988) into the unique MfeI site within the hrpL ORF. The chromosomal hrpL gene in $P$. carotovorum 35 was exchanged for the disrupted version using the exchange vector pRK415, as previously described. $P$. carotovorum 35 transconjugants were cultured twice in hrp-inducing minimal medium (Hyun et al., 1989). The putative mutants were selected for their kanamycin resistance and tetracycline sensitivity. The primer (forward: 5'-TTC CGT CAG TTT CTC GAT-3', reverse: 5'-AAA TCG CAT CCT TGA TAC GG-3') was designed on the basis of the $h r p L$ from $P$. carotovorum 35, and the identification of the $h r p L$ mutant was confirmed by PCR.

Virulence test. Four weeks after seeding in microtiter plates, tobacco plants were challenged with wild type P. carotovorum 35 or the hrpL mutant by pipetting $20 \mu \mathrm{l}$ of inoculum onto each leaf. The bacteria were grown for $24 \mathrm{~h}$ in LB broth, harvested by centrifugation, washed in sterile water, and resuspended in sterile distilled water at $\mathrm{OD}_{600 \mathrm{~nm}}=1.0$ (about $1 \times 10^{8} \mathrm{cfu} / \mathrm{ml}$ ). The wild-type and mutant cells were cultivated and centrifuged, washed in sterile water, and resuspended in sterile distilled water at $\mathrm{OD}_{600 \mathrm{~nm}}=1.0$. Distilled water was used as a control. For the studies conducted with the potato plant, the bacterial suspensions were pipetted onto potato slices, and incubated for $24 \mathrm{~h}$ at $30^{\circ} \mathrm{C}$. Virulence was scored according to the intensity of the water-soaked rotted lesions surrounding the inoculation site.

\section{Results}

BAC-end sequencing of the $P$. carotovorum 35 BAC library. The sequence analysis of a BAC library of 504 clones harboring partial fragments of genomic DNA from $P$. carotovorum 35 evidenced an average insert size of approximately $150 \mathrm{~kb}$, and enabled the construction of a physical map of $P$. carotovorum 35 for comparison with the genome of $P$. atroseptica 
SCRI1043. Detailed information concerning the BAC end sequences of $P$. carotovorum 35 is available at the homepage of the Plant Pathology Laboratory of Chonnam National University (http://ppmpmi.chonnam. ac.kr). The results of BAC end sequencing analysis demonstrated that the BAC library of $P$. carotovorum 35 harbored most of bacterial chromosome which covers approximately $4.6 \mathrm{Mb}$ chromosome (data not shown).

Cloning of the hrp cluster from BAC library. Sequencing of the subclones from the BAC clone E16 revealed a $24 \mathrm{~kb}$ hrp cluster with 26 open reading frames, which were grouped into five operons (Fig. 1) in the same order as the hrp gene cluster of $P$. carotovorum 35 (Lehtimaki et al., 2003). The deduced amino acid sequences of the hrp genes of $P$. carotovorum 35 evidenced a $92-99 \%$ identity with their $P$. carotovorum SCCI homologues (Table 2). The putative genes and their encoded functions are summarized in Table 2. Using $h r p L$ and $h r p J$ as reference loci, we predict that the hrp genes are likely to be transcribed in two directions, with the cluster of $h r p N, h r p V, h r p T, h r c C$, hrpG, hrpF, hrpE, hrpD, hrcJ, hrpB, hrpA, hrpS, hrpY, and $h r p X$ being transcribed in the same direction as $h r p L$, and opposite the transcriptional direction of $h r p J$, hrcV, hrpQ, hrcN, hrpO, hrpP, hrcS, hrcT, and hrcU

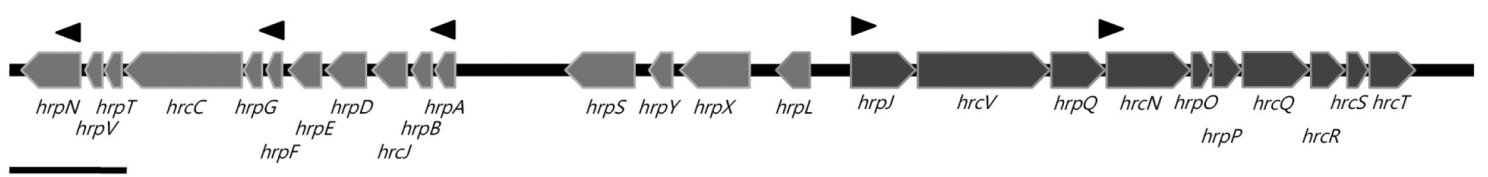

$2 \mathbf{k b}$

Fig. 1. The hrp gene cluster of Pectobacterium carotovorum subsp. carotovorum 35. The arrowheads indicate the predicted direction for the transcription of each gene. The hrp-boxes are marked with black arrowheads. The nucleotide sequences of the P. carotovorum 35 hrp genes are deposited in GenBank under Accession No. EU420066.

Table 2. Putative functions and identities of the Pectobacterium carotovorum 35 hrp genes

\begin{tabular}{|c|c|c|c|}
\hline Name of gene & $\begin{array}{l}\text { Hypothetical } \\
\mathrm{MW}(\mathrm{kDa}) / \mathrm{pI}\end{array}$ & Putative function of the gene & $\begin{array}{c}\text { Identity with Erwinia carotovora } \\
\text { SCCI (\%) }\end{array}$ \\
\hline$h r p N$ & $38 / 6.74$ & HR-inducer harpin & 93 \\
\hline$h r p V$ & $12 / 5.83$ & A negative regulator of transcription of the $h r p$ regulon & 92 \\
\hline hrpT & $6.9 / 8.63$ & A putative lipoprotein & 94 \\
\hline hrcC & $75 / 6.51$ & A secretion associated outer membrane & 98 \\
\hline hrpG & $14 / 4.82$ & An OmpR subclass of two-component response regulator & 98 \\
\hline$h r p F$ & $8 / 4.46$ & A putative type III translocon protein & 96 \\
\hline hrpE & $22 / 6.10$ & A $h r p$ pilin & 94 \\
\hline$h r p D$ & $23 / 6.95$ & A bitopic membrane protein & 94 \\
\hline$h r c J$ & $23 / 5.28$ & A putative outer membrane lipoprotein & 95 \\
\hline hrpB & $15 / 8.03$ & A positive regulator of pathogenicity gene & 96 \\
\hline hrpA & $6 / 5.96$ & A putative type III translocon protein & 98 \\
\hline$h r p S$ & $40 / 7.73$ & A putative NtrC like regulatory protein & 95 \\
\hline hrpY & $23 / 8.65$ & A putative two-component response regulator & 96 \\
\hline hrpX & $54 / 8.47$ & A putative two-component sensor kinase & 96 \\
\hline hrpL & $20 / 6.22$ & An alternative sigma factor for hrp genes & 99 \\
\hline hrpJ & $98 / 4.97$ & A putative hydrophilic-secretion protein & 97 \\
\hline$h r c V$ & $176 / 4.85$ & Type III secretion protein & 96 \\
\hline$h r p Q$ & $76 / 5.02$ & Type III secretion protein & 97 \\
\hline$h r c N$ & $112 / 4.93$ & Type III secretion cytoplasmic ATPase & 96 \\
\hline hrpO & $35 / 5.17$ & Secretion component, pathogenicity factor & 96 \\
\hline hrpP & $44 / 5.13$ & Type III secretion protein & 96 \\
\hline$h r c Q$ & $97 / 4.96$ & Type III secretion protein & 95 \\
\hline$h r c R$ & $54 / 5.11$ & Type III secretion protein & 96 \\
\hline$h r c S$ & $21 / 5.29$ & Type III secretion protein & 97 \\
\hline$h r c T$ & $68 / 5.06$ & Type III secretion protein & 95 \\
\hline
\end{tabular}


Table 3. Hrp boxes found in the promoter regions of various hrp genes in Erwinia carotovora SCC1 and Pectobacterium carotovorum 35

\begin{tabular}{|c|c|c|}
\hline Organism and operon & Promoter sequences and consensus sequences & Reference \\
\hline \multicolumn{3}{|l|}{ E. carotovora $\mathrm{SCCl}$} \\
\hline hrpA & 5'- CTTTTAGTTGGAACTCACTGACCCGCTCTCCCACTTAAATGAATGAA-3' & Rantakari et al. (2001) \\
\hline hrpC & CGTACGATGGGAACTGAGCAGGCAAGAAAATCACTTAAATGGGGGAG & Rantakari et al. (2001) \\
\hline$h r p N$ & CTGCCACTGGGAACTGCACGCTTAGGTTAACCACTCACTATTGAGT & Rantakari et al. (2001) \\
\hline hrpJ & TCACGTCGGGGAACCCATCCTTTTCTGCGTCCACACAGGAATACAT & Lehtima et al. (2003) \\
\hline$h r c N$ & 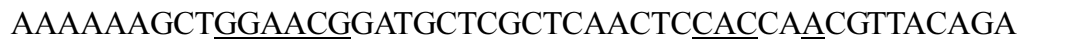 & Lehtima et al. (2003) \\
\hline \multicolumn{3}{|l|}{ P. carotovorum 35} \\
\hline hrpA & CTTTCCGTTGGAACTCACTGACCCGCTCTCTCACTTAAATGAATGA & This study \\
\hline$h r p G$ & TGCTAATGGGAACTGCACGCCGGGGTTAAC $\underline{\text { CACTCACTATTGAGT }}$ & This study \\
\hline$h r p N$ & CATAAGACGGGAACTGAGCACGCAAGGAAATAㅡ늣AGGGGGA & This study \\
\hline hrpJ & 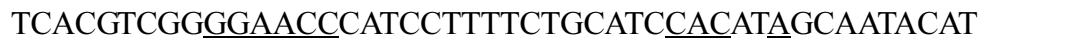 & This study \\
\hline$h r c N$ & AAAAAAGCTGGAACGGATGGCTCGCTCAACTCCACCAACGTTATAG & This study \\
\hline Consensus & GGAACc ------- 16bp space -------- cCACtcA & Fouts et al. (2002) \\
\hline
\end{tabular}

Table 4. Relative green fluorescence of HrpL-regulated genes from Pectobacterium carotovorum 35 as screened by the promoter-based GFP technology ${ }^{\mathrm{a}}$

\begin{tabular}{cccc}
\hline \hline Clone No. & Gene or function in E. carotovora ssp. & GFP with $h r p L(\mathrm{RLU})$ & GFP without $h r p L(\mathrm{RLU})^{\mathrm{b}}$ \\
\hline J11B and 100 clones & $h r p J$, typeIII secretion protein & $1,500-2,000$ & $100-200$ \\
J11C & pel, pectate lyase & $1,671 \pm 234$ & $234 \pm 54$ \\
J75B & large repetitive protein & $829 \pm 86$ & $87 \pm 23$ \\
\hline
\end{tabular}

${ }^{\mathrm{a}}$ The relative green fluorescence of each construct grown in LB broth was measured using a Fluorometer (FL $\times 800^{\mathrm{TM}}$ Multi-Detection Microplate Reader, Bio-Tek Inc., USA). Three independent experiments were repeated and the relative expression values are expressed as the means \pm SE of three experiments.

${ }^{\mathrm{b}}$ The control was Escherichia coli DH5 $\alpha$ containing vector only without co-expression of the hrpL gene.

(Fig. 1). Putative $h r p$ boxes were detected upstream of hrpJ, hrpA, hrpG, and hrpN (Fig. 1). The consensus sequence of the $h r p$ boxes, (GGAACc --16 bp space-cCACtcA), was identical between the SCCI and 35 strains (Table 3).

Screening of $h r p L$-regulated genes in $P$. carotovorum 35. In order to screen for HrpL-regulated genes, we employed an E. coli construct that constitutively generated HrpL via a plasmid harboring a construct of the open reading frame ligated to the promoter of the kanamycin resistance gene (nptII). The nptII promoter fusion resulted in a 13,000-fold stronger relative expression than that generated by the native promoter (data not shown). An initial screening revealed approximately 102 constructs that evidenced HrpL-dependent GFP expression (Table 4). The sequence analysis of these fusions showed that the majority of the selected clones contained the promoter for the hrpJ operon. Four other operons from the $h r p$ cluster, $h r p N, h r c N, h r p G$, and $h r p A$, all of which harbored hrp boxes, were not detected by the promoter-probe technology (Table 3). However, two other HrpL-dependent clones contained promoter sequences of a pel gene encoding for pectate lyase, and a gene encoding for large repetitive protein.

Expression of $h r p$ box-containing genes in the presence of $h r p L$ by promoter-probe technology. Via functional screening using the E. coli promoterprobe strategy, we determined that the hrpJ operon from P. carotovorum 35 was HrpL-dependent, whereas no enhanced expressions from the promoter sequences of the $h r p N, h r c N, h r p G$, and $h r p A$ operons were noted in these constructs (data not shown). However, the hrpJ promoter construct generated a stronger GFP signal (Table 4).

Expression and transcriptional regulation of $h r p L$ and $\boldsymbol{h r p} \boldsymbol{J}$ from $\boldsymbol{P}$. carotovorum 35. Expression from $h r p L$ and $h r p J$ was higher in the early log-phase $P$. carotovorum 35 cells $\left(\mathrm{OD}_{600 \mathrm{~nm}}=0.1\right)$ grown on the minimal medium than those grown in rich medium (Fig. 2). In both media, the transcript levels of hrpJ and $h r p L$ increased from the mid-log phase to the stationary phase (Fig. 2). The highest expression levels were detected in the stationary phase, bolstering the proposal of Chatterjee et al. (2002) that hrp genes are 
(A)

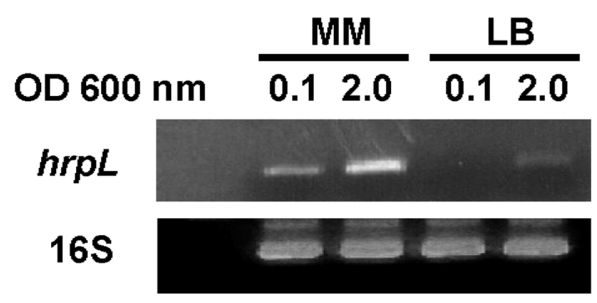

(B)
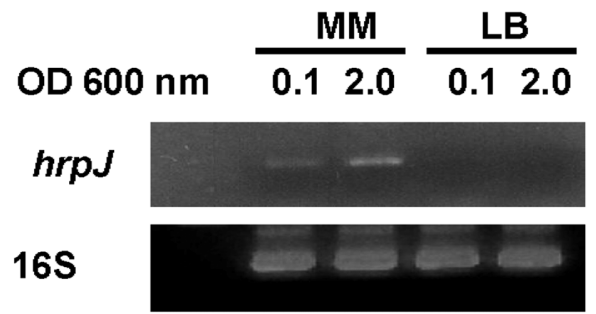

Fig. 2. Transcript accumulation of $h r p J$ and $h r p L$ in Pectobacterium carotovorum 35 at different growth phases and in two growth media. RNA was isolated from early log-phase $\left(\mathrm{OD}_{600 \mathrm{~nm}}=0.1\right)$ and stationary-phase $\left(\mathrm{OD}_{600 \mathrm{~nm}}=2.0\right)$ cells grown in $h r p$-inducing minimal medium and LB broth. RT-PCR analysis was conducted using specific primers for $h r p L$ (A) and $h r p J$ (B) or for the 16S rRNA gene transcripts as positive control. The PCR reactions were halted at the end of the $30^{\text {th }}$ cycle, and the PCR products were loaded onto $2 \%$ agarose gels for detection. The data shown are from one of three studies that generated similar results.
(A)

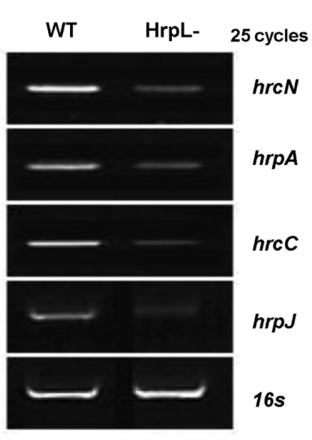

Hrp-inducing medium
(B)

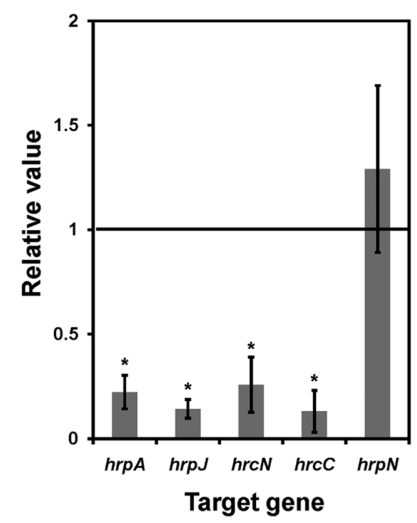

Fig. 3. Expression of $h r p J, h r p N, h r c C, h r c N$, and $h r p A$ in Pectobacterium carotovorum 35 and $h r p L$ mutants, as detected by qRT-PCR analysis. Total RNAs were isolated from $P$. carotovorum 35 and hrpL mutant cells grown to late-log phase $\left(\mathrm{OD}_{600 \mathrm{~mm}}=1.8\right)$ on the Hrp-inducing medium containing $0.1 \%$ glucose. Quantitative RT-PCR analysis was conducted using specific primers for $h r p$ genes or for the 16S rRNA gene transcripts as positive controls. The PCR reactions were halted at the end of the $25^{\text {th }}$ cycle, and the PCR products were loaded onto $2 \%$ agarose gels for detection. The data shown are one of three studies that generated similar results. The relative expression values are from three independent experiments, and the mean expression values are provided. *indicates a significant difference in the relative expression of the genes as shown by ANOVA analysis $(\mathrm{P}<0.05)$.
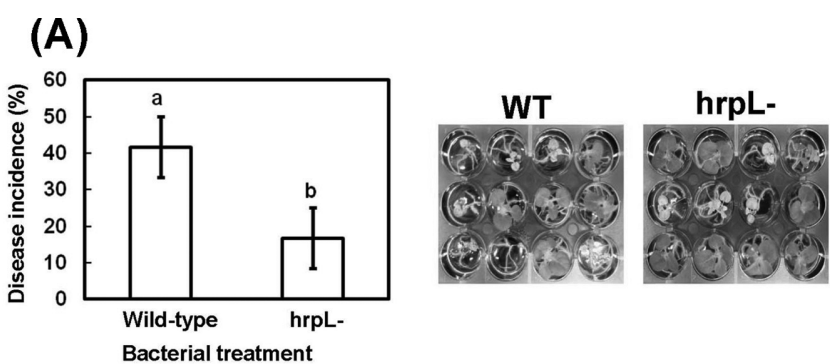

(B)
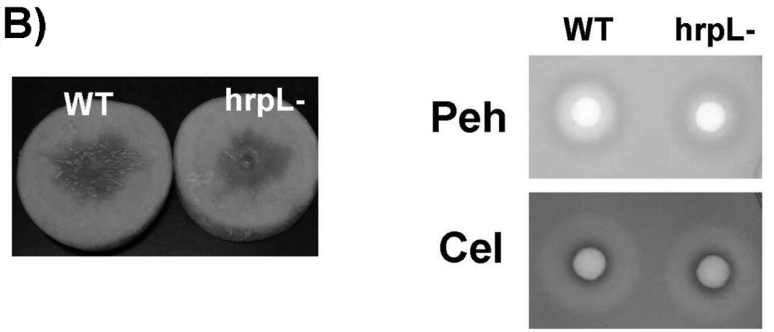

Fig. 4. Virulence test of the wild-type and mutant strains on tobacco plants and potato slices. (A) Three-week-old plants were inoculated with bacterial suspensions of the wild-type or $h r p L$ mutant containing $1 \times 10^{8} \mathrm{cfu} / \mathrm{ml}$ on the surfaces of tobacco leaves. The photographs were taken $48 \mathrm{~h}$ post inoculation. $(B)$ Potato slice inoculated with $10 \mu \mathrm{l}$ of the wild-type or $h r p L$ mutant, $1 \times 10^{8} \mathrm{cfu} / \mathrm{ml}$. Agarose plate assays of polygalaturonase (Peh), and cellulase (Cel) activities of Pectobacterium carotovorum 35 wild-type and $h r p L$ strain. Bacteria were grown at $28^{\circ} \mathrm{C}$ in $h r p$ inducing medium to stationary growth phase and cultural supernatants were used for the assay. Each well contained $10 \mu \mathrm{l}$ of culture supernatant. The photographs were taken 4 days after inoculation.

induced under nutrient-limited conditions in $P$. carotovorum.

Transcriptional analysis of hrp genes in the $h r p L$ mutant. Transcripts of the hrp operons harboring the Hrp box in their promoters, specially the hrpJ, $h r c N$, $h r p G$, and $h r p A$ operons, were reduced significantly in the $h r p L$ mutant relative to the wild-type strain (Fig. 3). Transcript levels from another potentially HrpL-regulated gene, $\operatorname{rrpN}$, were not detectable in the wild-type or the hrpL mutant strains (Fig. 3). Thus, HrpL strongly regulated $h r p J$, and was involved in expression from the $\operatorname{hrp} G$ and $h r p A$ operons, but was not operative in the regulation of the $h r p N$ gene.

Effect of the hrpL mutation on pathogenicity and secretion of enzyme activities. When the inocula of the hrpL mutant and wild-type strains were applied to tobacco leaf surface, the induced soft-rot symptoms were less severe in the hrpL mutant-treated plants relative to the wild-type treated leaves (Fig. 4A). By way of contrast, both the wild-type and hrpL mutant induced extensive maceration when inoculated onto sliced potato samples (Fig. 4B). Production of the 
extracellular enzymes, pectin-degrading enzymes and cellulase were not different between the wild-type and hrpL mutant (Fig. 4B).

\section{Discussion}

$P$ carotovorum causes severe soft-rot in Chinese cabbage all over the world, and no effective approaches to the control of this pathogen have yet been developed. Control strategies might arise from a better understanding of mechanisms underlying the pathogenicity of this particular bacterium. The hrp gene cluster in plant bacterial pathogens plays a role both in pathogenicity and in the triggering of the hypersensitive response. $P$. carotovorum strain 35 harbors an hrp cluster with genes with high identity and order relative to that of $P$. carotovorum SCCI (Lehtimaki et al., 2003).

The expression of some $h r p$ genes depends on the alternative sigma factor, HrpL (Wei and Beer, 1995), which is encoded within the hrp cluster. Both HrpS and another alternative sigma factor, RpoN, are known to be involved in the regulation of $h r p L$ expression in P. carotovorum 71 (Chatterjee et al., 2002). The promoter sequence of $h r p L$ in P. carotovorum 35 was similar to that in isolate 71 (Chartterjee et al., 2002), showing two potential RpoN-binding sites, between nucleotides -24 and -7 (GGctGGcacaagGCttGC), and an integration host factor (IHF)-binding site between nucleotides -130 and -115 , TTGCAAgaacTTGCAA. Consequently, regulation in the isolate 35 may also involve RpoN and IHF, as suggested in a previous study (Chatterjee et al., 2002).

The hrp cluster genes have been less well characterized in the soft rot bacteria than in the biotrophic bacterial pathogens, such as Pseudomonas syringae pv. tomato DC300. In isolate 35, we observed the $35 \mathrm{hrp}$ box, 5'GGAACCNA-N ${ }_{15-16}$-CCACNNA-3', located within the promoters of the $h r p$ operons or genes as described for other isolates (Fouts et al., 2002; Nissan et al., 2005; Xiao and Hutcheson, 1994). Using a GFP-based promoter probe approach we determined that one gene in the hrp cluster, hrpJ, was regulated by $\mathrm{HrpL}$, and that this gene harbored a putative HrpL binding box. The expression from hrpJ was correlated with that from $h r p L$ for different growth media during the culture phase. However, two other genes selected for their possessing of HrpL-activated promoters, one encoding for a pectate lyase and the second for a large repetitive protein, lacked hrp boxes and other conserved sequences. So far, there is no direct evidence that the transcriptional regulation of the pectate lyase and large repetitive genes occurs in an HrpL-dependent fashion.
Therefore, we are currently attempting to ascertain whether HrpL binds to the promoters of these genes. It has been previously reported that the overexpression of the $h r p L$ gene may induce the atypical expression of some genes (Chang et al., 2005).

We demonstrated that the production of extracellular pectinases, cellulase, and protease enzymes was not altered in the hrpL mutant of $P$. carotovorum 35. Because these extracellular enzymes are key virulence factors for the development of soft-rot symptoms (Andro et al., 1984; Collmer and Keen, 1986), this finding is consistent with the observed ability of the hrpL mutant to cause soft rot on sliced potato samples at the wildtype level. However, the severity of soft-rot symptoms was reduced profoundly in the $h r p L$ mutant when inoculated onto the tobacco leaf surface, mimicking a natural infection process. This finding was consistent with previous reports of the reduced pathogenicity of the HrpL mutant of D. dadantii (Shi and Cooksey, 2009 ) and the $\mathrm{HrcC}$ mutant of $P$. carotovorum (Rantakari et al., 2001) on susceptible host plants. Thus, HrpL may regulate other genes involved in the development of soft-rot symptoms. In conclusion, our results suggest that $\mathrm{HrpL}$ is involved in expression from the $h r p$ genes harboring the $h r p$ box in their promoters, and is also involved in the development of soft rot in the tobacco plant. However, the function of $\mathrm{HrpL}$ in isolate 35 did not appear to involve the production of extracellular plant cell wall-degrading enzymes. We are currently conducting a more detailed analysis of the regulation of the $h r p$ cluster expression P. carotovorum 35 .

\section{Acknowledgement}

This work was supported by a grant from the Technology Development Program for Agriculture and Forestry, Ministry of Agriculture and Forestry, Republic of Korea.

\section{References}

Andro, T., Chambost, J.-P., Kotoujansky, A., Cattaneo, J., Bertheau, Y., Barras, F., Van Gijsegem, F. and Coleno, A. 1984. Mutants of Erwinia chrysanthemi defective in secretion of pectinase and cellulose. J. Bacteriol. 160: 1199-1203.

Antonarakis, S. E. 2001. BAC king up the promises. Nature Genet. 27: 230-232.

Ausubel, F. M., Brent, R., Kingston, R. E., Moore, D. D., Seidman, J. G., Smith, J. A. and Struhl, K. 1989. Current Protocols in Molecular Biology, John Wiley and Sons, New York. 
Barras, F., Thurn, K. K. and Chatterjee, A. K. 1987. Resolution of four pectate lyase structural genes of Erwinia chrysanthemi (EC16) and characterization of the enzymes produced in Escherichia coli. Mol. Gen. Genet. 209: 319-325.

Bell, K. S., Avrova, A. O., Holeva, M. C., Cardle, L., Morris, W., Jong, W. D., Toth, I. K., Waugh, B., Bryan, G. J. and Birch, P. R. J. 2002. Sample sequencing of a selected region of the genome of Erwinia carotovora subsp. atroseptica reveals candidate phytopathogenicity genes and allows comparison with Escherichia coli. Microbiol. 148: 1367-1378.

Bell, K. S., Sebaihia, M., Pritchard, L., Holden, M. T. G., Hyman, L. J., Holeva, M. C., Thomson, N. R., Bentley, S. D., Churcher, L. J. C., Mungall, K., Atkin, R., Bason, N., Brooks, K., Chillingworth, T., Clark, K., Doggett, J., Fraser, A., Hance, Z., Hauser, H., Jagels, K., Moule, S., Norbertczak, H., Ormond, D., Price, C., Quail, M. A., Sanders, M., Walker, D., Whitehead, S., Salmond, G. P. C., Birch, P. R. J., Parkhill, J. and Toth, I. K. 2004. Genome sequence of the enterobacterial phytopathogen Erwinia carotovora subsp. atroseptica and characterization of virulence factors. Proc. Natl. Acad. Sci. USA. 101: 11105-11110.

Birnboim, H. C. and Doly, J. 1979. A rapid alkaline extraction procedure for screening recombinant plasmid DNA. Nucleic Acids Res. 7: 1513-1523.

Chang, J. H., Urbach, J. M., Law, T. F., Arnold, L. W., Hu, A., Gombar, S., Grant, S. R., Ausubel, F. M. and Dangl, J. L. 2005. A high-throughput, near-saturating screen for type III effector genes from Pseudomonas syringae. Proc. Natl. Acad. Sci. USA. 102: 2549-2554.

Chatterjee, A. K., Thurn, K. K. and Tyrell, D. J. 1985. Isolation and characterization of Tn5 insertion mutants of Erwinia chrysanthemi that are deficient in polygalacturonate catabolic enzymes oligogalacturonate lyase and 3-deoxy-D-glycero2,5-hexodiulosonate dehydrogenase. J. Bacteriol. 162: 708714.

Chatterjee, A., Ciu, Y. and Chatterjee, A. K. 2002. Regulation of Erwinia carotovora $h r p L_{E c c}$ (sigma- $\mathrm{L}_{E c c}$ ), which encodes an extracytoplasmic function subfamily of sigma factor required for expression of the HRP regulon. Mol. Plant-Microbe Interact. 15: 971-980.

Collmer, A. and Keen, N. T. 1986. The role of the pectic enzymes in plant pathogenesis. Annu. Rev. Phytopathol. 24: 383-409.

Del Sal, G., Manfioletti, G. and Schneider, C. 1989. The CTABDNA precipitation method: A common mini-scale preparation of template DNA from phagemids, phages or plasmids suitable for sequencing. BioTechniques 7: 514-520.

Elhai, J. and Wolk, C. P. 1988. A versatile class of positive selection vectors based on the nonviability of palindrome containing plasmids that allows cloning into long polylinkers. Gene 68: 119-138.

Fouts, D. E., Abramovitch, R. B., Alfano, J. R., Baldo, A. M., Buell, C. R., Cartinhour, S., Chatterjee, A. K., D'Ascenzo, M.,
Gwinn, M. L., Lazarowitz, S. G., Lin, N. C., Martin, G. B., Rehm, A. H., Schneider, D. J., van Dijk, K., Tang, X. Y. and Collmer, A. 2002. Genomewide identification of Pseudomonas syringae pv. tomato DC3000 promoters controlled by the HrpL alternative sigma factor. Proc. Natl. Acad. Sci. USA. 99: 2275-2280.

Frederick, R. D., Ahmad, M., Majerczak, D. R., ArroyoRodriguez, A. S., Manulis, S. and Coplin, D. L. 2001. Genetic organization of the Pantoea stewartii subsp. stewartii hrp gene cluster and sequence analysis of the $h r p A, h r p C, h r p N$, and wtsE operons. Mol. Plant-Microbe Interact. 14: 1213-1222.

Glasner, J. D., Marquez-Villavicenco, M., Kim, H.-S., Jahn, C. E., Ma, B., Biehl, B. S., Rissman, A. I., Mole, B., Yi, X., Yang, C.-H., Dangl, J. L., Grant, S. R., Perna, N. T. and Charkowski, A. O. 2008. Niche-specificity and the variable fraction of the Pecotobacterium pan-genome. Mol. Plant-Microbe Interact. 21: $1549-1560$.

Huynh, T. V., Dahlbeck, D. and Staskawicz, B. J. 1989. Bacterial blight of soybean: regulation of a pathogen gene determining host cultivar specificity. Science 245: 1374-1377.

Lehtimaki, S., Rantakari, A., Routtu, J., Tuikkala, A., Li, J., Virtaharju, O., Palva, E. T., Romantschuk, M. and Saarilahti, H. T. 2003. Characterization of the hrp pathogenicity cluster of Erwinia carotovora subsp. carotovora: high basal level expression in a mutant is associated with reduced virulence. Mol. Gen. Genom. 270: 263-272.

Livak, J. K. and Schmittgen, T. D. 2001. Analysis of relative gene expression data using real-time quantitative PCR and the $2^{-\Delta \Lambda C T}$ method. Methods 25: 402-408.

Ma, Z., Weining, S., Sharp, P. J. and Liu, C. J. 2000. Non-gridded library: a new approach for bacterial artificial chromosome (BAC) exploitation in hexaploid wheat (Triticum aestivum). Nucleic Acids Res. 2: e106.

Miller, W. G., Leveau, J. H. J. and Lindow, S. E. 2000. Improved $g f p$ and inaZ broad-host-range promoter-probe vectors. Mol. Plant-Microbe Interact. 13: 1243-1250.

Murata, H., McEvoy, J. L., Chatterjee, A., Collmer, A. and Chatterjee, A. K. 1991. Molecular cloning of an aepA gene that activates production of extracellular pectolytic, cellulolytic, and proteolytic enzymes in Erwinia carotovora subsp. carotovora. Mol. Plant-Microbe Interact. 4: 239-246.

Nissan, G., Manulis, S., Weinthal, D. M., Sessa, G. and Barash, I. 2005. Analysis of promoters recognized by $\mathrm{HrpL}$, an alternative $\sigma$-factor protein from Pantoea agglomerans pv. gypsophilae. Mol. Plant-Microbe Interact. 18: 634-643.

Perombelon, M. C. M. and Salmond, G. P. C. 1995. Bacterial soft rots. In : Pathogenesis and Host Specificity in Plant Diseases, ed. by U. S. Singh, R. P. Singh and K. Kohmoto, Vol. 1, pp. 17, Oxford: Pergamon Press.

Rantakari, A., Virtaharju, O., Vahamiko, S., Taira, S., Palva, E. T., Saarilahti, H. T. and Romantschuk, M. 2001. Type III secretion contributes to the pathogenesis of the soft-rot 
pathogen Erwinia carotovora: partial characterization of the hrp gene cluster. Mol. Plant-Microbe Interact. 14: 962-968. Sambrook, J., Frithsch, E. F. and Maniatis, T. 1989. Molecular Cloning: A Laboratory Manual. 2nd Ed., Cold Spring Harbor Laboratory Press, Cold Spring Harbor, NY.

Shi, X.-Y. and Cooksey, D. A. 2009. Identification of hrpL upregulated genes of Dickeya dadantii. Eur. J. Plant Pathol. 124: $105-116$.

Shin, Y.-J. 2004. Biological control of soft rot of Chinese cabbage by a bacteriocin-producing avirulent mutant of Erwinia carotovora subsp. carotovora. MS thesis. Chungbuk National University.

Wei, Z. M. and Beer, S. V. 1995. hrpL activites Erwinia amylovora hrp gene transcription and is a member of the ECF subfamily of sigma factors. J. Bacteriol. 177: 6201-6210.
Wei, Z. M., Kim, J. F. and Beer, S. V. 2000. Regulation of hrp genes and type III protein secretion in Erwinia amylovora by HrpX/HrpY, a novel two-component system, and HrpS. Mol. Plant-Microbe Interact. 13: 1251-1262.

Xiao, Y. and Hutcheson, S. W. 1994. A single promoter sequence recognized by newly identified alternative sigma factor direct expression of pathogenicity and host range determinants in Pseudomonas syringae. J. Bacteriol. 176: 3089-3091.

Yang, S., Perna, N. T., Cooksey, D. A., Okinaka, Y., Lindow, S. E., Ibekwe, A. M., Keen, N. T. and Yang, C.-H. 2004. Genome-wide identification of plant-upregulated genes of Erwinia chrysanthemi 3937 using a GFP-based IVET leaf array. Mol. Plant-Microbe Interact. 9: 999-1008.

Zhang, H. B. and Wing, R. A. 1997. Physical mapping of the rice genome with BACs. Plant Mol. Biol. 35: 115-127. 